\title{
Synthesis of collagen from Bali cattle's hide using a combination of acid and alkali on the extracting process
}

\author{
M. I. Said, Burhan, Tensi and Haerati \\ Faculty of Animal Science, Hasanuddin University, \\ Jl. Perintis Kemerdekaan Km.10 Makassar, Indonesia 90245 - Indonesia \\ *CorrespondingE-mail:irfanunhas@gmail.com;irfan.said@unhas.ac.id \\ Received January 16, 2018; Accepted May 18, 2018
}

\begin{abstract}
ABSTRAK
Tahap proses pra-ektraksi merupakan tahapan penting dalam proses sintesis kolagen. Tahap ini meningkatkan sensitivitas terhadap rantai molekul kolagen yang dapat mempengaruhi hasil produksi maupun sifat-sifat kolagen. Tujuan penelitian adalah untuk mensintesis dan mengevaluasi kolagen halal dari kulit Sapi Bali pada proses praekstraksi berbeda. Sebanyak 5 perlakuan diterapkan dalam penelitian ini, yaitu: $\mathrm{T}_{0}=$ Kontrol (tanpa perendaman) ; $\mathrm{T}_{1}=\mathrm{Ca}(\mathrm{OH})_{2} 5 \%(\mathrm{~b} / \mathrm{v}) ; \mathrm{T}_{2}=\mathrm{Ca}(\mathrm{OH})_{2} 15 \%(\mathrm{~b} / \mathrm{v}) ; \mathrm{T}_{3}=$ $\mathrm{Ca}(\mathrm{OH})_{2} 5 \%+\mathrm{CH}_{3} \mathrm{COOH} 5 \%(\mathrm{~b} / \mathrm{v}) ; \mathrm{T}_{4}=\mathrm{Ca}(\mathrm{OH})_{2} \quad 15 \%+\mathrm{CH}_{3} \mathrm{COOH} 5 \%(\mathrm{~b} / \mathrm{v})$. Masing-masing perlakuan diulang 4 kali. Data dianalisis secara sidik ragam menggunakan program SPSS. Parameter uji terdiri atas, rendemen, viskositas dan $\mathrm{pH}$. Hasil penelitian menunjukkan bahwa perbedaan proses praekstraksi nyata meningkatkan rendemen maupun viskositas, namun tidak pada nilai $\mathrm{pH}$. Penerapan perlakuan $\mathrm{T}_{4}$ memberikan hasil terbaik dibanding perlakuan lainnya maupun kontrol dalam meningkatkan rendemen dan juga memperbaiki sifat fisik kolagen dan $\mathrm{pH}$.
\end{abstract}

Kata kunci : kolagen, kulit Sapi Bali, praekstraksi, asam, basa

\begin{abstract}
The process of pre-extraction is an important stage in the process of collagen synthesis. This stage increases the sensitivity of collagen molecule chains that can affect production yields and collagen properties. The objectives of the study were to synthesize and evaluate halal collagen from Bali cattle's hide on different -extracting processes. A total of 5 treatments applied in this study, namely: $\mathrm{T}_{1}=$ $\mathrm{Ca}(\mathrm{OH})_{2} 5 \%(\mathrm{~b} / \mathrm{v}) ; \mathrm{T}_{2}=\mathrm{Ca}(\mathrm{OH})_{2} 15 \%(\mathrm{~b} / \mathrm{v}) ; \mathrm{T}_{3}=\mathrm{Ca}(\mathrm{OH})_{2} 5 \%+\mathrm{CH}_{3} \mathrm{COOH} 5 \%(\mathrm{~b} / \mathrm{v}) ; \mathrm{T}_{4}=\mathrm{Ca}(\mathrm{OH})_{2}$ $15 \%+\mathrm{CH}_{3} \mathrm{COOH} 5 \%(\mathrm{~b} / \mathrm{v})$. Each treatment was repeated 4 times. Data were analyzed in a variety of ways using SPSS program. The observed parameters consisted of: 1) yield, 2) viscosity and 3) $\mathrm{pH}$. The results showed that the difference in real pre-extracting process increased the yield and viscosity, but not the $\mathrm{pH}$ value. The application of $\mathrm{T}_{4}$ treatment provided the best results compared to other treatments as well as controls to increase the yield and also improve the collagen's physical properties and $\mathrm{pH}$.
\end{abstract}

Keywords: collagen, Bali cattle's hide, pre-extraction, acid, alkali

\section{INTRODUCTION}

The need of collagen for human needs every year is increasing. Thus, humans are expected to find potential sources of collagen. One source of collagen is cattle hide (Grobben et al., 2004 ; Jongjareonrak et al., 2008). Collagen fibers are the major mechanical component in the 
extracellular matrix of multicellular animals from the echinoderms to vertebrates. Fibril collagen is a network that forms a stable body frame (Holmes et al., 2018). Collagen is the main structure of vertebrate animals containing approximately 30\% of the total body protein (Chen et al., 2015).

Collagen was needs for industrial raw materials, both food and non-food industries that increases every year (Veeruraj et al., 2015). Currently, as many as 29 types of collagen molecules have been identified. All these collagen molecules have differences in the order of peptides, structures and functions (Yousefi et al., 2017; Zhou et al., 2016).

The supply of collagen is still dependent on imported products, while the potential of raw materials in the country is very large. The use of raw materials from the skin and pig bones is a problem for the Islamic countries.

One of the current problems is related to the aspect of collagen halality. Halal collagen marketed by several countries in Europe and America is still in doubt. This issue is quite groundless, because collagen as the base material of capsule shell (pharmaceutical industry) is imported product (Hidaka and Liu, 2002). Collagen used in many Muslim countries is mostly imported from American and European countries. These countries generally produce collagen from pig skin $(46 \%)$, cow hide $(29 \%)$, cow bones (23.1\%) and other sources (1.5\%). This is done because the raw material price is relatively cheap (Karim and Bhat, 2008). In addition, these countries were identified with many cases of foot and mouth disease (FMD) (Grobben et al., 2004 ; Nagai et al., 2008 ; Barzideh et al., 2014 ; Huang et al., 2016).

In Indonesia, hide from Bali cattle has a huge potential to be developed as a raw material for collagen synthesis. Beef cattle are one of the livestock species that have the largest population after poultry and goat. These are data of poultry population $(2,175,613,000$ heads $)$ goats $(18,410,000$ heads) and beef cattle $(16,599,000$ heads) (Ministry of Agriculture of the Republic of Indonesia, 2017). Hide of Bali cattle is a halal product that can be accepted by the Muslim community, so it is potential to be developed as a raw material for collagen synthesis.

The process of collagen synthesis involves a reaction process between a chemical compound and skin protein. In the process of collagen synthesis, the use of materials from acids and alkali as a pre-extraction material is still being studied by several researchers (Kittiphattanabawon et al., 2005; Kasankala et al., 2007). It aims to produce collagen products that have better properties (Said, 2014). The application of acid and alkali processes in the process of collagen synthesis has an effect on the properties of collagen (Wang et al., 2008; Zeugolis et al., 2008). Acid affects the amount of dissolved collagen. Increased acid concentration has increased solubility of collagen. Acids and bases will affect the $\mathrm{pH}$ value of the solution. Furthermore, changes in solution $\mathrm{pH}$ lead to the occurrence of protein denaturation associated with the amount of dissolved collagen. Acids will break bond structures from the triple helix into mono helix, while the base will break the bonding structure from triple helix to bi helix (Wang et al., 2008). The combination of acids and bases in the pre-treatment process will maximize the yield of the reaction process and improve the stability and properties of collagen. Collagen molecules consist of three polypeptide chains ( $\alpha$-chains), which are in a triple-helix conformation. This conformation is stabilized by intra-hydrogen bonds and inter-protein collagen. Acid and base contamination affects the bonding structure that affects amino acid bonds. The occurrence of the initial denaturation process by the integration of acids and bases will soften the bonding structure. Finally, the extraction process has to be maximized in order to increase the yield value.

This study aims were to evaluate the process of acid and base reaction and its combination in the pre-extraction stage made from Bali cattle's hide on collagen properties.

\section{MATERIALS AND METHODS}

\section{Research Materials}

The raw material of collagen synthesis is Bali cattle's hide obtained from Animal Slaughtering House (ASH) at Tamangapa village, Makassar city, South Sulawesi province, Indonesia. Hides were obtained from Bali cattle male, 2.5-3 years old. The synthesis process materials consisted of $\mathrm{Ca}(\mathrm{OH})_{2} 5 \%$ and $15 \%(\mathrm{w} / \mathrm{v}$ solution) (CV.Sumber Rejeki, Indonesia), $\mathrm{CH}_{3} \mathrm{COOH} 5 \%$ (v/v) (SIGMA Lab.), aquadest (Lab of Chemical and Animal Feed, Faculty of Animal Science, Hasanuddin University, Makassar, Indonesia). The synthesis equipments were water bath (Memmert WNB7-45), electric oven (Memmert), beaker glass (Pyrex), measuring cylinders (Pyrex), analytical scales 
(RADWAG PS $600 / \mathrm{C} / 2$ ), glass funnel (Pyrex), thermometer, and viscometer (Brookfoeld LV), $\mathrm{pH}$ meter (Hanna).

\section{MATERIALS AND METHODS}

\section{Experimental Study}

A total of $5 \mathrm{~kg}(5,000 \mathrm{~g})$ from Bali cattle's hide was used as a research samples. The sample in fresh condition and clean (without hair) was cut rectangle with size $2 \times 3 \mathrm{~cm}$. The sample was allocated for 5 treatments with 4 replications (5x4). Each treatment unit uses $250 \mathrm{~g}$ of hide sample.

The study was conducted experimentally based on Completely Randomized Design of Directional Pattern $5 \times 4, \mathrm{~T}_{0}=$ control (without preextracting process); $\mathrm{T}_{1}=\mathrm{Ca}(\mathrm{OH})_{2} 5 \%(\mathrm{w} / \mathrm{v}) ; \mathrm{T}_{2}=$ $\mathrm{Ca}(\mathrm{OH})_{2} \quad 15 \%(\mathrm{w} / \mathrm{v}) ; \mathrm{T}_{3}=\mathrm{Ca}(\mathrm{OH})_{2} \quad 5 \%(\mathrm{w} / \mathrm{v})+$ $\mathrm{CH}_{3} \mathrm{COOH} 5 \%(\mathrm{v} / \mathrm{v}) ; \mathrm{T}_{4}=\mathrm{Ca}(\mathrm{OH})_{2} \quad 15 \%(\mathrm{w} / \mathrm{v})+$ $\mathrm{CH}_{3} \mathrm{COOH} \quad 5 \% \quad(\mathrm{v} / \mathrm{v})$. Each treatment was repeated 4 times. The flowchart of the collagen production process was presented in Figure 1.

\section{Preparation of Bali Cattle's Hide}

The initial process was weighing raw material (Bali cattle's hide). Furthermore, the hide was immersed in water at $70^{\circ} \mathrm{C}$ for $15 \mathrm{~min}$ for the unhairing process preparation. Hairs of the hide were then removed through a manual process. The hide was washed with running water for $10 \mathrm{~min}$. The hide was cut into small size of $2 \times 3 \mathrm{~cm}$, then it was ready for use as a raw material for further collagen synthesis.

\section{Preparation of Collagen Synthesis Process}

The synthesis process refers to the process performed by Ockerman and Hansen (2000) with modification. A total of 5 pieces of beaker glass was prepared for treatment containers of $\mathrm{T}_{0}$ (control), $\mathrm{T}_{1}, \mathrm{~T}_{2}, \mathrm{~T}_{3}$, and, $\mathrm{T}_{4} \cdot \mathrm{Ca}(\mathrm{OH})_{2}$ and $\mathrm{CH}_{3} \mathrm{COOH}$ solutions (according to each treatment) were each inserted into the beaker glass. Furthermore, as much as $250 \mathrm{~g}$ of Bali cattle's hide as raw material each was put into 5 pieces of beaker glass. Bali cattle's hide was then soaked for 4 days at room temperature. The hide sample was then removed from the beaker glass and washed with running water. Bali cattle's hide samples were further extracted in water bath at $60-70^{\circ} \mathrm{C}$ for $24 \mathrm{~h}$. The extraction results were then filtered to produce filtrate of liquid collagen extract. The result was then dried in an oven at $60^{\circ} \mathrm{C}$ for $24 \mathrm{~h}$ to produce a dry collagen extract. Collagen extract was milled using a grinder and then packed with vacuum plastic for further testing. The flowchart of the collagen synthesis process was presented in Figure 1.

\section{Data Analysis}

The data of the study included: yield, viscosity and $\mathrm{pH}$ value were analyzed statistically with ANOVA (Steel and Torrie, 1991). Data processing was using SPSS software.

Yield $(\%)=(\mathrm{AxB}) \times 100 \%$, where $\mathrm{A}=$ weight of solid collagen extract (g); B = weight of Bali cattle's hide ( $\mathrm{g}$ ) according to Giménez et al. (2005b).

Viscosity (cP) was determined using viscometer (Brookfoeld LV) according to (Arnesen and Gildberg, 2002).

Solid collagen extract was made into a solution with a concentration of $6.67 \%(\mathrm{w} / \mathrm{v})$. The solution was inserted into the viscometer using a speed of $30 \mathrm{rpm}$. The equation used was Viscosity $(\mathrm{cP})=$ Factor $\mathrm{x}$ DR, where Factor $=2$; DR (deal reading) $=$ scale recorded at the viscometer tool

$\mathrm{pH}$. The $\mathrm{pH}$ value was determined by using $\mathrm{pH}$ meter (Hanna). A total of $0.5 \mathrm{~g}$ of dried gelatin was dissolved into $20 \mathrm{~mL}$ of aquadest. $\mathrm{pH}$ meter was connected with electrode. The calibration process was carried out at $\mathrm{pH} 4.00$ and 7.00. After the next calibration process, then the measurement was done.

\section{RESULTS AND DISCUSSION}

\section{Yield}

The yield of a product was assumed the number of end products that can be harvested from the amount of processed material (Giménez et al., 2005a). The average value of yield (\%) of collagen from Bali cattle's hide on different preextracting processes was presented in Figure 2.

Figure 2 shows that the difference of material type applied in pre-extraction process has significant effect $(\mathrm{P}<0.05)$ on the value of yield. The application of acids and alkali at the pre-extracting process was produce varying yield values. Pre-extracting treatment using acid and alkali increased the yield value compared to the control (without pre-extracting process). Based on Figure 2, the highest value of collagen yield was in $\mathrm{T}_{1}$ treatment $(28.68 \%)$, then $\mathrm{T}_{2}(24.62 \%) ; \mathrm{T}_{3}$ $(23.63 \%)$ and the lowest was $\mathrm{T}_{4}(23.23 \%)$. The result of Bali cattle's hide collagen extraction is 


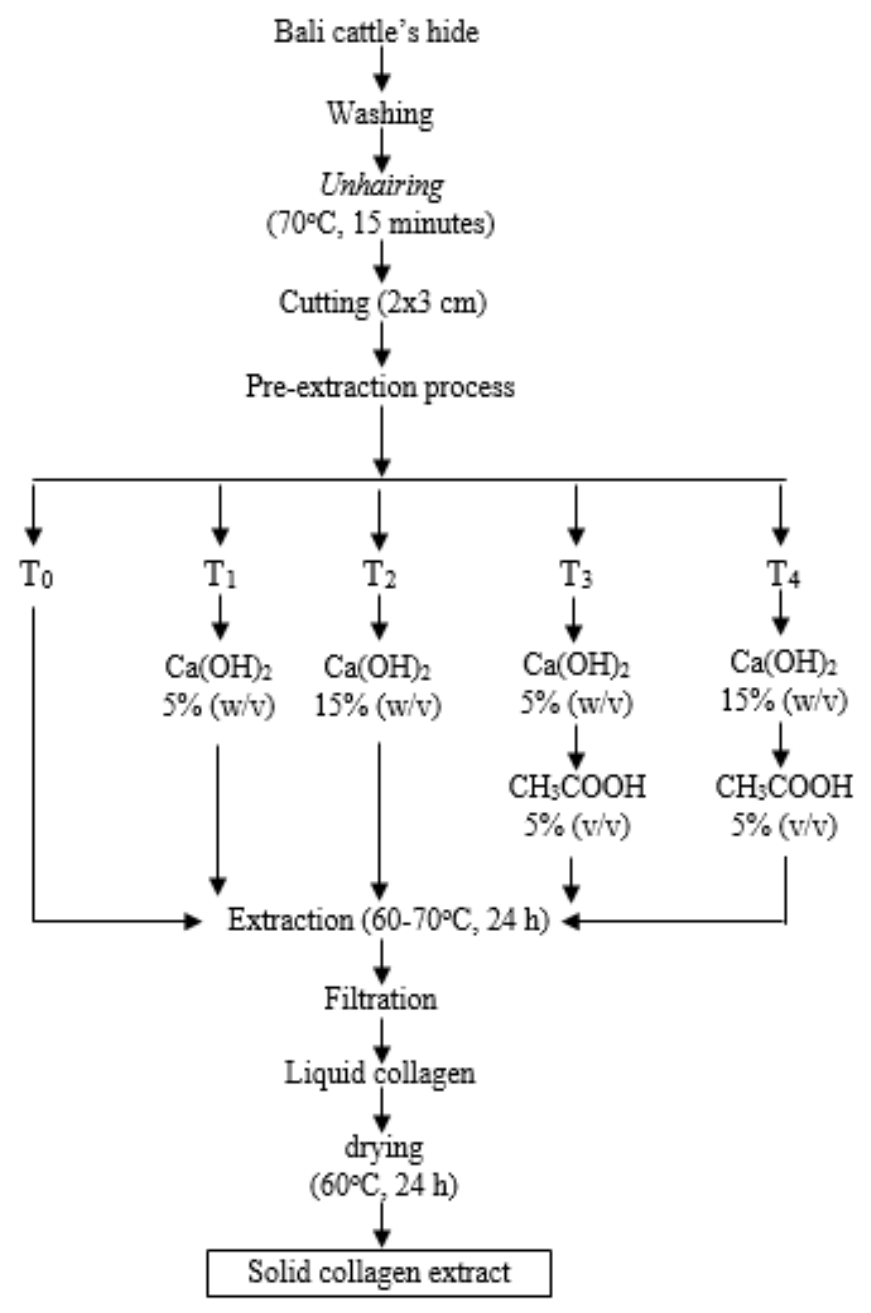

Figure 1. Flow chart of the synthesis process of collagen extract from Bali cattle's hide on the different pre-extracting processes.

still lower than collagen extract from skin of sole fish skin. On the application of $0.54 \mathrm{M}$ acetic acid for 32.32 hours gave a yield value of $19.27 \pm 0.05$ $\mathrm{mg} / \mathrm{g}$. These results are due to the skin of the fish having weak amino acid molecule bonds that are easier decomposed and converted into dissolved collagen. In addition, the age of the fish is younger than the cows so that the strength of the molecular structure becomes weak (Arumugam et al., 2018). The more hydrolyzed collagen, it will increase the water holding capacity of the gel. This affects the decreasing of power drop (Abdollahi et al., 2018).

The process of pre-treatment of Bali cattle skin takes longer than the skin of rabbit and fish. Rabbit skin takes only 22-24 hours to produce maximum collagen (Ma et al., 2018). Among the several collagen molecules present in animals, type I collagen is the most important type of collagen as a source of peptides in the protein structure (Zhang et al., 2013; Tamilmozhi et al., 2013). The acid-soluble collagen and in the pepsin-soluble have been extracted from the skin of Pacific cod skin fish (Gadus macrocephalus). The collagen form is type I with an alpha chain structure of $\alpha 12 \alpha 2$ (Sun et al., 2017).

In addition to acids and bases, the use of enzymes has also been applied in the process of collagen extraction from chicken leg skin. The yield was $32.16 \%$ with application at $30^{\circ} \mathrm{C}$. This result is higher than Bali cow leather. This is because poultry (chicken) has a shorter life. It affects the bonding of collagen molecules. At a short age, collagen molecule bonds will break easily which can increase the yield during the extraction process (Dhakal et al., 2018). 


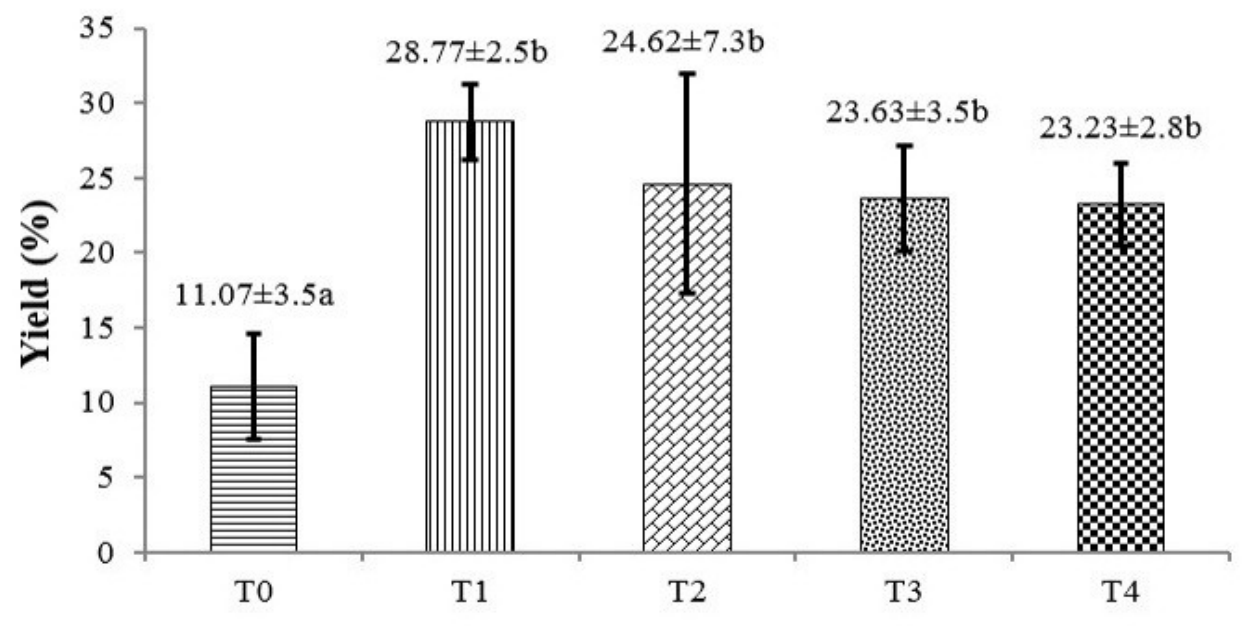

Treatment of Pre-extraction Process

Figure 2. The value of yield (\%) of collagen from Bali cattle's hide on treatment of different preextracting processes; $\mathrm{T} 0=$ control (without pre-extracting process); $\mathrm{T} 1=\mathrm{Ca}(\mathrm{OH})_{2} 5 \%(\mathrm{w} / \mathrm{v}) ; \mathrm{T} 2=$ $\mathrm{Ca}(\mathrm{OH})_{2}{ }_{15 \%}(\mathrm{w} / \mathrm{v}) ; \mathrm{T} 3=\mathrm{Ca}(\mathrm{OH})_{2} 5 \%(\mathrm{w} / \mathrm{v})+\mathrm{CH}_{3} \mathrm{COOH} 5 \%(\mathrm{v} / \mathrm{v}) ; \mathrm{T} 4=\mathrm{Ca}(\mathrm{OH})_{2} 15 \%(\mathrm{w} / \mathrm{v})+$ $\mathrm{CH}_{3} \mathrm{COOH} 5 \%(\mathrm{v} / \mathrm{v})$; Differences superscript show significantly different $(\mathrm{P}<0.05)$

Increased acid concentration may decrease collagen thermo stability and increase collagen yield (from $64 \%$ increase up to $80 \%$ ). The content of the sub unit component in collagen in pretreatment will decrease as the acid concentration is increased Zhang et al., 2016).

Rapid hydrolysis rate of collagen tended to increase the number of collagen molecules that were converted and will eventually increase the yield value (Muyonga et al., 2003). Treatment of pre-extracting processes in the production process of collagen affected the yield (Kasankala et al., 2007). The process of destruction of covalent bonds (acid or base) increased the yield of collagen. However, if the process of destruction was too much, it will reduce the collagen results in the next process. This resulted in lower production yields (Sarbon et al., 2013). The change in acid concentration affected the value of yield (Zhou and Joe, 2005). Increased acid concentration causes an increase the concentration of $\mathrm{H}^{+}$ions. This can affect the hydrolysis process. According to Kołodziejska et al. (2007), the processes applied in the synthesis of collagen affected the yield. The yield of collagen produced from Bali cattle's hide was not much different from the yield of collagen from goat skin of previous research which was $1.90-12.95 \%$ (Said et al., 2015).

\section{Viscosity}

Viscosity is the phenomenon of an object to hold a liquid to flow (Schrieber and Gareis, 2007). Acid and alkali treatment in the preextracting process affects the viscosity of collagen. Viscosity testing was performed to determine the degree of viscosity of collagen as a solution at a certain concentration and temperature. The denaturation temperature difference of each ingredient used is influenced by the difference of the hydroxyproline content of each ingredient. The amino acid content of proteins is related to the temperature stability of collagen (Gauza-Włodarczyk et el., 2017). A covalent bond between molecules inside the collagen fiber (intra-fibrillar crosslinks) affects the physical strength of collagen fibers in the extracellular matrix (Cumming et al., 2018).

The average value of the collagen viscosity of Bali cattle's hide on different pre-extracting processes is presented in Figure 3. The preextracting treatment has significantly affected the value of the collagen viscosity. The results of the viscosity test at each treatment varied from 5.67$7.5 \mathrm{cP}$. The result of statistical test showed that acid and alkali treatment at pre-extracting stage had significant effect $(\mathrm{P}<0.05)$ on collagen viscosity properties. $T_{4}$ treatment has the highest viscosity value compared to other treatments. Increased viscosity values can be affected by the 


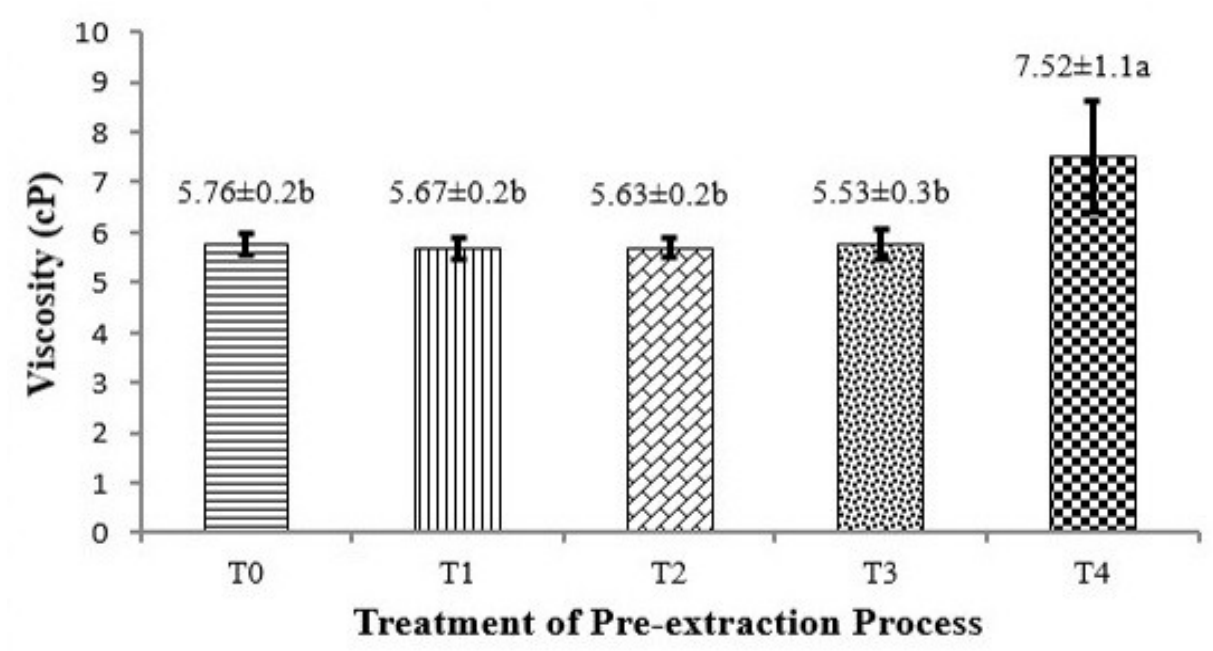

Figure 3. The value of viscosity $(\mathrm{cP})$ of collagen from Bali cattle's hide on treatment of different preextracting processes (19); $\mathrm{T} 0=$ control (without pre-extracting process); $\mathrm{T} 1=\mathrm{Ca}(\mathrm{OH})_{2} 5 \%(\mathrm{w} / \mathrm{v}) ; \mathrm{T} 2=$ $\mathrm{Ca}(\mathrm{OH})_{2} 15 \%(\mathrm{w} / \mathrm{v}) ; \mathrm{T} 3=\mathrm{Ca}(\mathrm{OH})_{2} 5 \%(\mathrm{w} / \mathrm{v})+\mathrm{CH}_{3} \mathrm{COOH} 5 \%(\mathrm{v} / \mathrm{v}) ; \mathrm{T} 4=\mathrm{Ca}(\mathrm{OH})_{2} 15 \%(\mathrm{w} / \mathrm{v})+$ $\mathrm{CH}_{3} \mathrm{COOH} 5 \%(\mathrm{v} / \mathrm{v})$; Differences superscript show significantly different $(\mathrm{P}<0.05)$

structure of amino acid molecules that make up collagen proteins.

An increasingly long array of amino acids will increase the value of the collagen viscosity Collagen has soluble and insoluble properties. This may affect its viscosity value (Ledwar, 2000). Fibril collagen is one of the factors making up of extracellular matrix (Corre-Bordes et al., 2018). Collagen Hydrogel has been used everywhere as a biomaterial engineering with a biphasic collagen fibrillar network. This material contributes to complex, compressible, nonlinear, mechanical properties with very little strain (Lane et al., 2018).

Collagen telopeptides determine the intermolecular interaction. This will have an effect on the stabilization of the triple helix structure of the collagen. The amino acid composition is responsible for the difference in the isoelectric point of the collagen molecule. In addition, the variation in the distribution of amino acid residues has an important role to influence the viscosity of the solution (Gao et al., 2018).

Increased levels of acetic acid concentration in the process of collagen synthesis can decrease the value of viscosity. This is because the preextracted solution has "broken" the amino acid peptide bond into a very short chain of molecules, so that its viscosity decreases. On the other hand, increasing the concentration of the pre-extracting solution may also increase the viscosity value.
This occurs when the pre-extracting solution was capable of "breaking" the peptide bond at the proper bond into longer molecules. The value of the collagen viscosity produced was relatively similar to the collagen viscosity obtained by Songchotikunpan et al. (2007) with the ingredients of the Tilapia Nile fish (Oreochromis niloticus) of $1.78 \mathrm{cP}$. The peptide release method in the hydrolysis process can be used to evaluate food products. Based on these instructions then peptides can be utilized to produce food (Chen et al., 2018).

In the reaction process, the acid particles initially damage the intermolecular covalent bonds and covalent bonds in non-helical crystallizations. The peptide bond can then be destroyed when the molecular bond of some of its subunits has weakened. The peptide bond can then be destroyed when the molecular bond of some of its subunits has weakened. FTIR and SEM analyze showed that pretreatment acid treatment can destroy some of the original collagen structures in a short time. Meanwhile, collagen showed having a wavy fold regularly. As the acid pretreatment continues, the collagen structure will form a new conformation through a new hydrogen bond, and the surface fold became smaller (Ma et al., 2018).

Collagen from cattle hide was potential to be utilized as the base material of edible film for environmentally friendly packaging material. The 


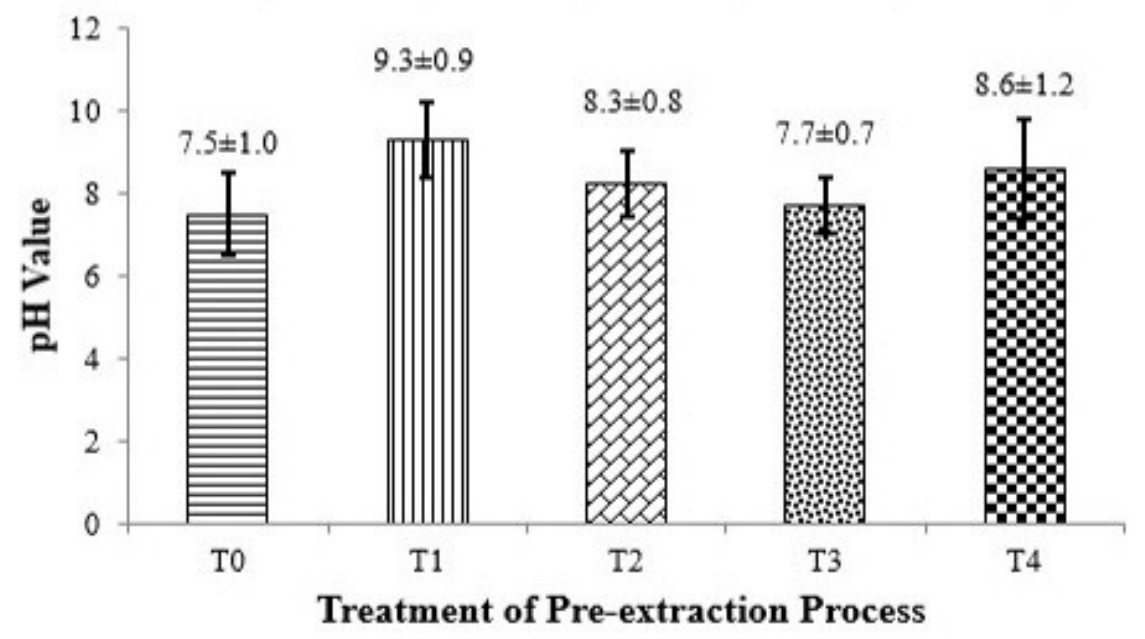

Figure 4.The value of $\mathrm{pH}$ of collagen from Bali cattle's hide on treatment of different pre-extracting processes (19)

collagen may be combined with other ingredients to improve the edible properties of the film (Said et al., 2016).

\section{pH}

The value of $\mathrm{pH}$ (potential hydrogen) of collagen is one of the important parameters in the quality standard of collagen. The $\mathrm{pH}$ value is not an absolute scale, but is relative (Buck et al., 2001). The average value of $\mathrm{pH}$ of collagen from Bali cattle's hide in the treatment of different preextracting processes was presented in Figure 4.

Figure 4 shows that the difference of preextracting process did not show significant effect on the $\mathrm{pH}$ value of collagen. The pre-extracting process used several types of solutions that were not different from the treatments. The $\mathrm{pH}$ value of the collagen product in the $\mathrm{T}_{1}-\mathrm{T}_{4}$ treatments was higher than those in the control treatment $\mathrm{pH}\left(\mathrm{T}_{0}\right)$. This is because the pre-extracting solution used mostly from the alkali group, so the $\mathrm{pH}$ value is also in an alkaline atmosphere. The addition of acidic processes to $T_{3}$ and $T_{4}$ treatments did not change the atmosphere to acid. This was because the alkali concentration was still higher than the acid concentration during the pre-extracting process. At the time of acid and alkali enhancement in the pre-extracting process, the collagen fibers of the skin sweall. This results in a decrease in the internal cohesion properties of the skin fibers (Ockerman and Hansen, 2000) (Burhan et al., 2017). The process of breaking up collagen molecules is partially related to the strain and stress properties of collagen fibril fibers
(Hamedzadeh et al., 2018).

The application of alkaline treatment in the pre-extracting process of goat skin has also been applied by previous researchers (Said et al., 2011). The results show the similarity in particular to the $\mathrm{pH}$ value (7.28-7.48)

\section{CONCLUSION}

The treatment of $\mathrm{T}_{4}$ (combination of $\mathrm{Ca}(\mathrm{OH}) 215 \%(\mathrm{w} / \mathrm{v})$ with $\mathrm{CH} 3 \mathrm{COOH} 5 \%(\mathrm{v} / \mathrm{v}))$ showed the best pre-treatment during production process of collagen from Bali cattle's hide compared to other treatments $\left(\mathrm{T}_{0}, \mathrm{~T}_{1}, \mathrm{~T}_{2}\right.$ and $\left.\mathrm{T}_{3}\right)$ because of producing a maximum yield, improving the physical properties of collagen and having the $\mathrm{pH}$ constant as well.

\section{ACKNOWLEDGMENT}

The team of authors would like to thank the Ministry of Research, Technology and Higher Education, Republic of Indonesia and Rector of Hasanuddin University for funding support through the Grant of Program Kreativitas Mahasiswa Penelitian Eksakta (PKM-PE), Hasanuddin University with contract number 10925/UN4.1.3/PM.05/2017.

\section{REFERENCES}

Abdollahi, M., M.Rezaei, A.Jafarpour and I. Undeland. 2018. Sequential extraction of gel-forming proteins, collagen and collagen 
hydrolysate from gutted silver carp (Hypophthalmichthys molitrix), a biorefinery approach. Food Chemistry. 242: 568-578.

Arnesen, J.A and A.Gildberg. 2002. Preparation and characterization of gelatine from the skin of harp seal (Phoca groendlandica). Bioresource Technology. 82:191-194.

Arumugam, G.K.S., D. Sharma, R.M. Balakrishnan and J.B.P. Ettiyappan. 2018. Extraction, optimization and characterization of collagen from sole fish skin. Sustainable Chemistry and Pharmacy. 9: 19-26.

Barzideh, Z., A. A. Latiff, C. Y. Gan, S . Benjakul, and A.A. Karim. 2014. Isolation and characterisation of collagen from the ribbon jellyfish (Chrysaora sp.). Intl. J Food Sci. and Tech. 49: 1490-1499.

Buck, R.P., S.Rondinini, A.K.Covington, F.G.K.Baucke, C.M.A.Brett, M.F.Camoes, M.J.T. Milton, T.Mussini, R.Naumann, K.WPratt, P.Spitzer and G.S.Wilson. 2001. The measurement of $\mathrm{pH}$ - definition, standards and procedures. [Report of the Working Party on $\mathrm{pH}$, IUPAC Provisional Recommendation].

Burhan, Tensi, Haerati and M.I. Said. Rendemen dan Kualitas Gelatin Kulit Sapi Bali Pada Proses Perendaman Berbeda. Prosiding. Seminar Nasional Peternakan. Fakultas Peternakan Universitas Hasanuddin, Makassar. 18-19 September 2017.

Chen, Y., R.Ye, and Y.Wang, Y. 2015. Acidsoluble and pepsin-soluble collagens from grass carp Ctenopharyngodon idella) skin: a comparative study on physicochemical properties. Intl. J Food Science and Tech. 50: 186-193.

Chen, J., L.Li, R.Yi, R.Gao and J. He. 2018. Release kinetics of Tilapia scale collagen I peptides during tryptic hydrolysis. Food Hydrocolloids. 77: 931-936.

Corre-Bordes, D.L., K.Hofman and B.Hall. 2018. Guide to electrospinning denatured whole chain collagen from hoki fish using benign solvents. International Journal of Biological Macromolecules. 112: 12891299.

Cumming, M.H., A.R. Leonard, D.S. LeCorreBordes and K. Hofman. 2018. Intra-fibrillar citric acid crosslinking of marine collagen electrospun nanofibres. Int. J. Bio. Macromol. 114: 874-881.
Dhakal, D., P.Koomsap, A.Lamichhane, M.B. Sadiq and A.K. Anal. 2018. Optimization of collagen extraction from chicken feet by papain hydrolysis and synthesis of chicken feet collagen based biopolymeric fibres. Food Bioscience. 23: 23-30.

Gao, L.L., Z.Wang, Z. Li, C.Zhang and D. Zhang. 2018. The characterization of acid and pepsin soluble collagen from ovine bones (Ujumuqin sheep). J. Integrative Agric. 17(3): 704-711.

Gauza-Włodarczyk, M., L.Kubisz, S.Mielcarek and D.Włodarczyk. 2017. Comparison of thermal properties of fish collagen and bovine collagen in the temperature range 298-670K. Materials Sci. Engineer. 80:468-471.

Giménez, B., M.C.Gómez-Guillén and P.Montero. 2005a. The role of salt washing of fish skins in chemical and rheological properties of gelatinextracted. Food Hydrocolloids. 19(6): 951-957.

Giménez, B., M.C.Gómez-Guillén and P.Montero. 2005b. Storage of dried fish skins on quality characteristics of extracted gelatin. Food Hydrocolloids. 19(6):958963.

Grobben, A.H., P.J. Steele, R.A.Somerville and D.M.Taylor. 2004. Inactivation of the bovine-spongiform-encephalopathy (BSE) agent by the acid and alkali processes used in the manufacture of bone kolagene. Biotechnol. App. Biochem. 39:329-338.

Hamedzadeh, A., T.C. Gasser and S.Federico. 2018. On the constitutive modelling of recruitment and damage of collagen fibres in soft biological tissues. European J. Mechanics -A Solids. 72: 483-496.

Hidaka, S. and S.Y. Liu. 2002. Effect of collagens on calcium phosphate precipitation : a possible application for distinguishing bovine bone collagen from porcine skin kolagen. J. Food. Compos. Anal. 16:477483.

Holmes, D.F., Y.Lu, T.Starborg and K.E.Kadler. 2018. Collagen Fibril Assembly and Function, Current Topics in Developmental Biology. Academic Press.

Huang, C.Y., J.M. Kuo, S.J. Wu, and H.T.Tsai. 2016. Isolation and characterization of fish scale collagen from tilapia (Oreochromis sp.) by a novel extrusion-hydro-extraction process. Food Chem. 190: 997-1006. 
Jongjareonrak, A., S. Benjakul, W. Visessanguan and M. Tanaka. 2008. Antioxidative activity and properties of fish skin gelatin films incorporated with BHT and $\alpha$ tocopherol.Food Hydrocolloids. 22(3):449458.

Karim, A.A and R. Bhat. 2008. Fish kolagen: properties, challenges, and prospects as an alternative to mammalian kolagens. Food Hydrocolloids. 23(3):563-576.

Kasankala, L.M., Y. Xue, Y. Weilong, S.D. Hong, Q. He. 2007. Optimization of gelatine extraction from grass carp (Catenopharyngodon idella) fish skin by response surface methodology.Bioresource Technol. 98(17):3338-3343.

Kittiphattanabawon, P., S. Benjakul, W. Visessanguan, T. Nagai, M. Tanaka. 2005. Characterisation of acid-soluble collagen from skin and bone of bigeye snapper (Priacanthus tayenus). Food Chem. 89:363-372.

Kołodziejska I, E. Skierka, M. Sadowska, W. Kołodziejski and C. Niecikowska. 2007. Effect of extracting time and temperature on yield of gelatin from different fish offal. Food Chem. 107(2):700-706.

Lane, B.A., K.A. Harmon, R.L. Goodwin, M.J. Yost, T. Shazly and J.F. Eberth. 2018. Constitutive modeling of compressible type-I collagen hydrogels. Med. Eng. and Phys.. 53: 39-48.

Ledwar, D.A. 2000. Gelation. Food Sci. Technol. Today. 6(4);236-241.

Ma, M., L.Ma, W.Yu, X.Zhang, Y.Shen and Y.Zhang. 2018. Research on rapid gelatinization of rabbit skin collagen as effect of acid treatment. Food Hydrocolloids. 77: 945-951.

Ministry of Agriculture of The Republic of Indonesia. 2017. Livestock and Animal Health Statistics 2017, Jakarta.

Muyonga, J.H., C.G.B.Cole and K.G.Duodu. 2003. Fourier transform infrared (FTIR) spectroscopic study of acid soluble collagen and gelatin from skins and bones of young and adult Nile perch (Lates niloticus). Food Chem. 86(3):325-332.

Nagai, T., N.Suzuki and T.Nagashima. 2008. Collagen from common minke whale (Balaenoptera acutorostrata) unesu. Food Chem. 111(2): 296-301.

Ockerman, H.W and C.L.Hansen. 2000. Animal by product processing and utilization. CRC
Press, USA.

Said, M.I., S. Triatmojo, Y. Erwanto and A. Fudholi. 2011. Gelatin properties of goat skin produced by calcium hydroxide as curing material. Media Peternakan. 34(3):184-189.

Said, M.I. 2014. By Product Ternak. Teknologi dan Aplikasinya. IPB Press, Bogor.

Said, M.I., E.Abustam, A.W.Wahab, Sartini and A.Hifizah. 2015. Chemical characteristics of collagen extract from scapula of bali cattle (os Scapula) produced using different extractant. Pak. J. Nutr. 14(3):174-179.

Said, M. I, Y. Erwanto, E. Abustam. 2016. Properties of edible film produced using combination of collagen extracts of Bligon goatskin with glycerol. American J. Anim. Vet. Sci. 11 (4):151-159.

Sarbon, N.M., F. Badii and N.K. Howell. 2013. Preparation and characterisation of chicken skin gelatin as an alternative to mammalian gelatin. Food Hydrocolloids. 30(1):143151.

Schrieber, R and H. Gareis. 2007. Gelatine Handbook, Wiley-VCH GmbH \& Co, Weinhem. 2007.

Songchotikunpan, P., J.Tattiyakul and P.Supaphol. 2007. Extraction and electrospinning of gelatin from fish skin. Int. J. Biol. Macromol. 42(3):247-255.

Steel, R.G.D and J.H.Torrie. 1991. Principle and procedure of statistics. $2^{\text {nd }}$ ed. International Book Company, Tokyo.

Sun, L., B.Li, W.Song, L.Si and H.Hou. 2017. Characterization of Pacific cod (Gadus macrocephalus) skin collagen and fabrication of collagen sponge as a good biocompatible biomedical material. Process Biochem. 63:229-235.

Tamilmozhi, S., V. Anguchamy and M. Arumugam, M. 2013. Isolation and characterization of acid and pepsinsolubilized collagen from the skin of sailfish (Istiophorus platypterus). Food Res. Int. 54: 1499-1505.

Veeruraj, A., M.Arumugam, T.Ajithkumar and T. Balasubramanian. 2015. Isolation and characterization of collagen from the outer skin of squid (Doryteuthis singhalensis). Food Hydrocolloids. 43: 708-716.

Wang, L., B.Yang, R.Wang, X.Du. 2008. Extraction of pepsin-soluble collagen from grass carp (Ctenopharyngodon idella) skin using an artificial neural network. Food. 
Chem. 111(3):683-686.

Yousefi, M., F. Ariffin, and N. Huda. 2017. An alternative source of type I collagen based on by-product with higher thermal stability. Food Hydrocolloids. 63: 372-382.

Zeugolis, D.I., S.T. Khew, E.S.Y. Yew, A.K. Ekaputra, Y.W. Tong, L.Y.Yung, D.W. Hutmacher, C. Sheppard and M. Raghunath. 2008. Electro-spinning of pure collagen nano-fibres - Just an expensive way to make gelatin? Biomaterials. 15:2293-2305.

Zhang, Y.H., K. Olsen, A. Grossi and J. Otte. 2013. Effect of pretreatment on enzymatic hydrolysis of bovine collagen and formation of ACE-inhibitory peptides. Food Chem. 141: 2343-2354.
Zhang, Y., L. Ma, L. Cai, M. Zhou and J. Li. 2016. Effects of acid concentration and the UHP pretreatment on the gelatinization of collagen and the properties of extracted gelatins. Int. J Food Sci. Technol. 51(5): 1228-1235.

Zhou, P and M.R.Joe. 2005. Effect of alkaline and acid pretreatments on alaska pollock skin gelatin extraction. J. Food Sci. 70:392-396.

Zhou, C.S., Y.H.Li, X.J.Yu, H.Yang, H.Ma, A.E.A. Yagoub, Y.Cheng, J.L.Hu, and P.N.Y. Out. 2016. Extraction and characterization of chicken feet soluble collagen. LWT - Food Science and Technol. 74:145-153. 